VERSITA

Original article

DOI: $10.2478 /$ rrlm-2013-0014

\title{
Evaluation of serum hepcidin variation in patients with rheumatoid arthritis according to anemia profile and its correlation with disease activity
}

\section{Evaluarea variației hepcidinei serice la pacienți cu poliartrită reumatoidă în funcție de prezența anemiei şi corelația sa cu activitatea bolii}

\author{
Adriana Sabău ${ }^{1}$, Madălina Văleanu ${ }^{2}$, Horațiu D. Boloşiu ${ }^{1}$, Alexandra M. Crăciun ${ }^{3 *}$ \\ 1. Department of Rheumatology, "Iuliu Hațieganu” University of Medicine and Pharmacy \\ Cluj-Napoca, Romania \\ 2. Deparment of Medical Informatics, "Iuliu Hațieganu” University of Medicine and Pharmacy \\ Cluj-Napoca, Romania \\ 3. Department of Medical Biochemistry, "Iuliu Hațieganu" University of Medicine and Pharmacy \\ Cluj-Napoca, Romania
}

\begin{abstract}
Objective: The objectives of this study were: determination of serum hepcidin levels in patients with Rheumatoid arthritis (RA) with/without anemia and controls, and its correlation with disease activity and anemia parameters. Patients and Methods: 69 people were involved in our study: 54 patients and 15 healthy subjects (controls). Laboratory evaluation of anemia, iron parameters, serum hepcidin levels and disease activity was carried out. RA patients were divided in two groups: anemic group and non-anemic group (NA), according to hemoglobin levels $(\mathrm{Hb})$. Soluble transferrin receptor-ferritin index (sTfR-F index) was used to classify anemia types: anemia of chronic disease (ACD) and anemia of chronic disease + iron deficiency anemia (ACD+IDA). Disease activity was evaluated using the following parameters: erythrocyte sedimentation rate (ESR), C-reactive protein (CPR), and disease activity score (DAS28). Results: ACD and ACD+IDA groups had significantly higher serum hepcidin concentrations than controls $(p<0.001, p<0.001)$, and NA group $(p=0.006, p=0.002)$. No difference in hepcidin levels was observed between ACD and ADC+IDA groups $(p=0.85)$ and between NA and controls $(p=0.66)$. ESR was significantly higher in ACD and ACD+IDA groups compared with NA group $(p<0.001$, $p=0.002)$ and controls. $(p<0.001, p<0.001)$.DAS 28 score was higher in anemic groups than NA group (ACD vs. $N A, p=0.01),(A C D+I D A$ vs. NA, $p=0.01)$ and no difference was observed between ACD and ACD+IDA In RA patients serum hepcidin concentration was significantly negatively correlated with hemoglobin $(H b)(r=-0.459$, $p<0.000)$ and serum iron $(r=-0.357, p<0.01)$ and positively with disease activity variables: ESR $(r=0.352$, $p<0.01), C R P(r=0.369, p<0.01)$, DAS28 score $(r=0.289, p<0.05)$. Conclusion: Hepcidin increases in RA patients with anemia and its levels correlate with $\mathrm{Hb}$, serum iron, and disease activity variables.
\end{abstract}

Keywords: hepcidin, anemia of chronic disease, rheumatoid arthritis, DAS28, C reactive protein, erythrocyte sedimentation rate, soluble transferring receptor.

*Corresponding author: Alexandra M Crăciun, "Iuliu Haţieganu” University of Medicine and Pharmacy ClujNapoca, Department of Medical Biochemistry, 6 Pasteur Louis Street, 400349 Cluj-Napoca. Email:acraciun@umfcluj.ro, Tel: 0040722348226, Fax: 0040264595965. 


\section{Rezumat}

Obiectivul acestui studiu a fost determinarea hepcidinei serice în concordanță cu profilul anemic la pacienții cu poliartrită reumatoidă $(P R)$ şi evaluarea corelației acesteia cu reactanții de fază acută (viteza de sedimentare a hematiilor (VSH), proteina $C$ reactivă (PCR) şi scorul de activitate al bolii (DAS28). Pacienți şi metode. Profilul anemic, reactanții de fază acută şi valorile hepcidinei serice au fost determinate la pacienții cu PR şi pentru lotul martor. DAS28 a fost calculat pentru toți pacienții cu PR. Pacienții cu anemie care au avut valorile sTfR-F index < 1.5 au fost considerați ca având anemie cronică secundară bolii(ACD), în timp ce pacienții care au avut sTfR (receptori solubili de transferina) $/ \log$ feritina $=(s T f R-F$ index $)<1.5$ au fost clasificați ca având anemie cronică secundară bolii cu deficit de fier asociat (ACD+IDA). Rezultate La pacienții cu PR(n=54), valorile hepcidinei serice s-au corelat pozitiv cu reactanții de fază acută: VSH, $(r=0.352, p<0.01), C R P(r=0.369$, $p<0.01)$, scorul DAS28 ( $r=0.289, p<0.05)$, şi negativ cu hemoglobina $(H b)(r=-0.459, p<0.000)$ şi cu fierul seric ( $r=-0.357, p<0.01$ ). Pacienții cu ACD şi ACD+IDA au prezentat valori semnificativ crescute comparativ cu pacienții din grupul non-anemic şi lotul martor. Nu s-au observat diferențe semnificativ statistic între grupul ACD şi ACD+IDA. Corelații semnificative s-au observat în grupul ACD+IDA între hepcidină şi parametrii caracteristici profilului anemic $\mathrm{Hb}(r=-0.51, p<0.05)$, TfS (saturația transferinei) $(r=-0.46, p<0.05)$ şi fier $(r=-0.43, p<$ 0.05). Concluzii. Hepcidina creşte la pacienții cu PR şi anemie, iar valorile serice ale acesteia se corelează cu inflamația, activitatea bolii precum şi cu $\mathrm{Hb}$ şi fierul seric.

Cuvinte cheie: hepcidina, anemia secundară bolilor cornice, anemie feriprivă, poliatrită reumatoidă, DAS 28.

Received: $16^{\text {th }}$ January 2013; Accepted: $28^{\text {th }}$ February 2013; Published: $11^{\text {th }}$ March 2013.

\section{Introduction}

RA is a chronic systemic inflammatory disease causing tissue inflammation that is mostly localized at the level of synovial joints. Anemia is a common morbidity in patients with RA (1). ACD and IDA are two most important types of anemia and often occur concurrently (2). ACD that develops in patients with RA is an immune-mediated process that involves cytokine synthesis. Results of immune activation induce changes in: iron homeostasis, erythroid progenitor cell proliferation, erythropoietin production, and life span of red cells (3). IDA in RA patients is attributed to iron deficiency, possibly caused by gastrointestinal bleeding associated with drug treatment or different malignancies (4). Hepcidin is an iron regulatory protein mainly produced in the liver (5) as a precursor (pro-hepcidin) (pre-prohepcidin) composed of 84 amino acids (6). The biologically active form (hepcidin 25) is secreted into plasma (7). At the present, two isoforms have been isolated, hepcidin 20 (in serum and urine) and hepcidin
22 (in urine), but the biological significance of these two forms remains unclear (8). Hepcidin acts by binding to the cellular iron exporter ferroportin inducing its internalization and degradation, and resulting trapping of iron in erythrocytes, macrophages and hepatocytes (9). Anemia, hypoxia and inflammation regulate hepcidin gene expression (10). The inflammatory cytokine interleukin 6 (IL-6) directly regulates hepcidin expression through the induction and subsequent promoter binding of signal transducer and activator of transcription (STAT3) (11). Hepcidin is considered a type II acute phase protein (12) and there are data that suggest that hepcidin is the key mediator of anemia of inflammation (13). ACD and IDA are frequently associated with RA and, although similar, their pathogenic mechanism is different and sometime difficult to differentiate. Moreover, ACD may coexist with IDA (ACD+IDA) in patients with RA. Bone marrow biopsy is considered the best method for diagnosing IDA in the presence of inflammation, but has the disadvantage of being an invasive and expensive diagnostic tool. Ferritin is used as 
a marker of for iron deficiency but even increased or normal values do not exclude with certainty the presence of iron deficiency, ferritin being an acute phase reactant which increases during inflammatory process (14). In both ACD and IDA, serum iron concentration and transferrin saturation are reduced, reflecting absolute iron deficiency in IDA and hypoferremia secondary to iron incorporation in macrophages in ACD (15). Soluble transferin receptor (sTfR) is truncated form of the tissue transferring receptor, present on cells that need iron (14) and most importantly, the serum concentration is not increased in inflammation or infection, unlike ferritin(14).

\section{Materials and Methods}

\section{Patients}

69 subjects were enrolled in this prospective study, 54 patients with RA and 15 healthy subjects (control group). All 54 patients met the revised criteria for RA diagnosis of the American College of Rheumatology (16), and control subjects were recruited from the hospital personnel, without any history of inflammatory disease. Exclusion criteria were macrocytosis, blood transfusion and iron supplementation in the last 3 month and recent acute blood loss. Moreover, patients were excluded if they had any signs or symptoms of renal, hepatic, endocrine, hematological, lymphoproliferative or malignant disease. Patients with acute or chronic infections were also excluded. The exclusion criteria for the control group were the same as those for the RA group. Clinical assessments included demographic data like age, gender and disease duration. Current medication, including non-steroidal anti-inflammatory drugs, steroids, DMARDs (disease modifying drug therapy) and biological treatment were documented. The study received all the necessary approvals from the Ethics Committee of the University Hospital Cluj-Napoca, and all patients agreed with study participation.

\section{Samples}

Blood was collected between 7:00 and 9:00AM on the day the clinical and joint examinations were performed. ESR and complete hemogram (cell blood count, CBC) were performed within 2 hours after blood collection on anticoagulant. For the rest of the markers, blood was collected in BD vacuum tubes without anticoagulant. Thirty minutes after blood collection, the tubes without anticoagulant were centrifuged at 3,000 g for 10 minutes. Serum was stored at $-80^{\circ} \mathrm{C}$ until serial testing.

\section{Laboratory evaluation of anemia}

Anemia was defined according to World Health Organization criteria from 1968. Male patients with hemoglobin $(\mathrm{Hb})<13 \mathrm{~g} / \mathrm{dl}$ and female patients with $\mathrm{Hb}<12 \mathrm{mg} / \mathrm{dl}$ were considered anemic (17) Complete hemogram, including $\mathrm{Hb}$ and hematocrit $(\mathrm{Ht})$ levels, platelet and leucocytes count were performed. Red cell indices such as MCV (mean corpuscular volume), mean corpuscular hemoglobin $(\mathrm{MCH})$, mean corpuscular hemoglobin concentration (MCHC) and red cell distribution width (RDW) ,were also carried outusing an Abacus junior automatic analyzer (Diatron, Austria). For all parameters in the complete hemogram, the inter-assay $\mathrm{CV}$ was a maximum of $2 \%$. Enzyme- linked immunosorbent assay (ELISA) was used for the quantitative serum determination of hepcidin and sTfR, and the measurements were performed on Elisa Reader 230S, Organon Teknika (Boxtel, The Netherlands). Serum hepcidin concentrations were evaluated using an ELISA commercial kit for hepcidin (Uscn Life Science Inc.Wuhan, China). The sensitivity of the method was $0.05 \mathrm{ng} / \mathrm{ml}$, and the detection range was between 0.188 and 12 $\mathrm{ng} / \mathrm{ml}$. Serum sTfR concentrations were established with a commercial test kit from R\&D Systems Inc (Minneapolis, USA). Method sensitivity was $0.5 \mathrm{nmol} / \mathrm{l}$ (intra-assay CV-5.86, inter-assay CV-5.83\%). sTfR values were converted from nmol to $\mathrm{mg} / \mathrm{l}$ using molecular weight of sTfR (18). As suggested by previous studies 
the ratio of sTfR to log ferritin(sTfR-Findex) (19), was used to diagnose different anaemic profiles in our patients $(3,20,21)$. A cut-off of 1.5 for sTfR-Findex as described in previous studies (22-24) was considered in classifying our patients with anemia. Patients with sTfR- F index value $<1.5$ were classified as having ACD and those with sTfR $-\mathrm{F}$ index $>1.5$ were classified as ACD+IDA. Serum ferritin concentration was assessed by electrochemiluminescence immunoassay (ECLIA) on an Elecsys 1010 automatic analyzer (Hoffman la Roche-Switzerland) using a commercial kit for ferritin from Roche Diagnostic (Mannheim, Germany). Quantitative serum iron determination was measured on a Cobas Mira plus automatic analyzer (Hoffman La Roche, Switzerland) using a colorimetric method (Ferrozine, Chemelex, Barcelona, Spain) (intra-assay CV of 4\%, inter-assay CV 6\%). Quantitative nephelometric determination of transferrin was established using the Turbox Transferrin kit (Orion Diagnostica, Finland) on a semi-automated analyser (Turbox plus, Orion Diagnostica, Finland). Total iron binding capacity (TIBC) and transferrin saturation (TfS) were calculated using the following formulas: $\operatorname{TIBC}(\mu \mathrm{mol} / \mathrm{l}=25.1 \times \mathrm{Tf}(\mathrm{g} / \mathrm{L}) \quad(25)$ and $\operatorname{TfS}(\%)=\mathrm{Fe}(\mathrm{mg} / \mathrm{L}) \times 70.9 / \mathrm{Tf}(\mathrm{g} / \mathrm{l})(26)$

Anemic patients were also examined for gastrointestinal blood loss by testing fecal occult blood (FOBT) using an immunological rapid test (Prevent ID, Preventis GmbH-Bensheim, Germany) which, according to the manufacturer, detects hemoglobin and hemoglobinhaptoglobin complex.

\section{Acute phase reactants}

ESR was effectuated by Westergreen technique and CRP was evaluated by a nephelometric metod on the Turbox plus semi-automated analyzer (Orion Diagnostica Finland) using a the Turbox CRP commercial kit (intra-assay CV $2.6 \%$ and inter-assay CV 6.8\%) from Orion Diagnostic Finland.

\section{DAS 28 score}

DAS 28 score is used in clinical practice and medical research to evaluate disease activity. 28 specific joints that are most frequently affected by the disease are evaluated by a specialist in joints examination. The number of painful and swollen joints, patient's global assessment of disease activity (visual analogue scale), and ESR or CRP are introduced in a mathematic formula for score calculation (27). In our study we used ESR for score calculation and the calculations were performed on a DAS score calculator used in medical practice. Joint examinations were performed on the day blood was collected, according to necessary standards.

\section{Statistical analysis}

The SPSS/IPC+ software package version 16.0 (SPSS Inc Chicago, USA) was used for statistical interpretation and graphical representations. Metric data were summarized as mean \pm standard deviation (SD) whenever the data proved to be normally distributed. The Shapiro-Wilk and Kolmogorov-Smirnov tests at the significance level of 5\% were used to test the normality. Student's t-test was used to compare the means of the two groups whenever data proven to be normally distributed. The means between more than two groups for normally distributed variables were tested by ANOVA and the post-hoc Tukey test was applied to compare the two groups. Non-parametric tests (Mann-Whitney, Krusball-Wallis, Median test) were used to test the normality.

\section{Results}

\section{Evaluation of anemia profile in $R A$ patients}

In the RA group $(\mathrm{n}=54), 43$ women (79.7\%) and 11 men (20.3\%) were enrolled. The control group had a similar distribution, 13 women $(86.7 \%)$ and 2 men (13.3\%). In the RA group, 38 patients $(70.4 \%)$ had anemia (the anemic group) and the rest (29.6\%) did not (the non-anemic group). Patients from the anemic group with sTfR-F index $<1.5$ were sub-classified as the ACD group $(n=19)$ and patients with sTfR-F index $>1.5(n=19)$ were classified as the ACD+IDA group. The ages of the patients were 


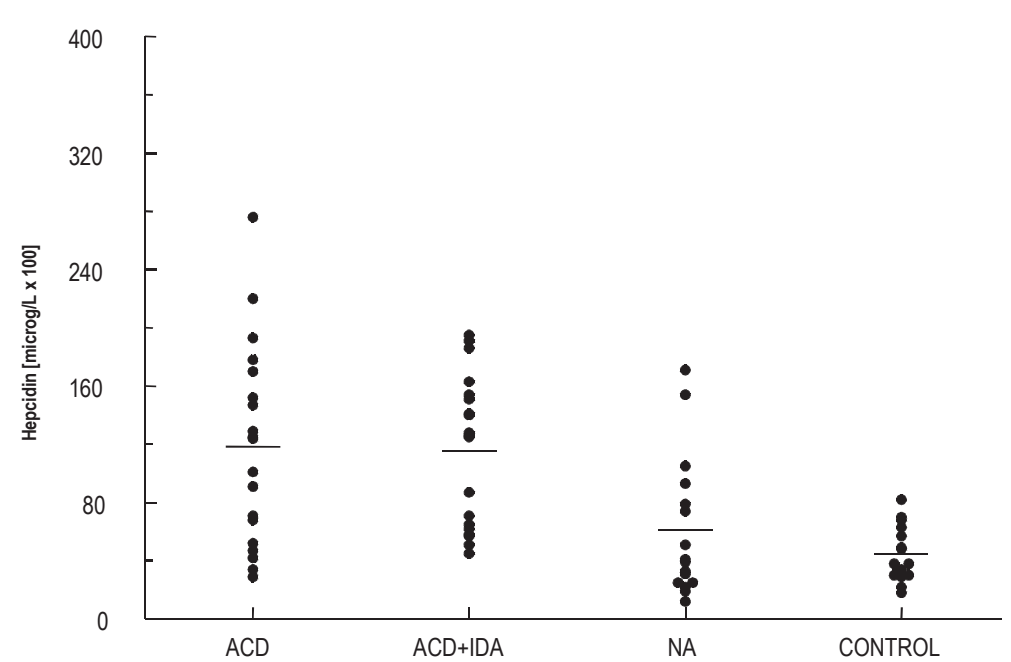

Figure 1. Hepcidin levels in the serum of RA patients $(n=54)$ and healthy subjects $(\mathbf{n}=\mathbf{1 5})$. The RA group was subdivided into three groups: ACD $(n=19), \operatorname{ACD}+\operatorname{IDA}(n=19)$ and NA $(n=16)$.

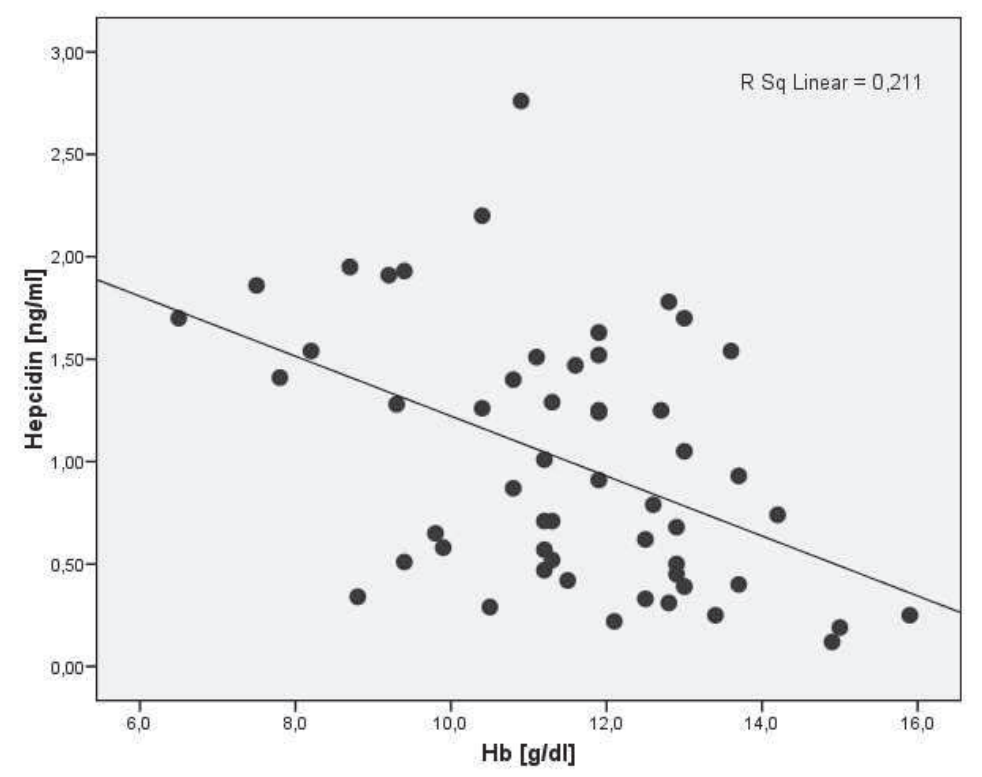

Figure 2. Hepcidin-Hb regression in patients with $\mathrm{RA}(\mathrm{n}=\mathbf{5 4})$.

$10.68 \pm 10.89$ years for the anemic group and $9.37 \pm 5.40$ years for the non-anemic one $(\mathrm{p}>0.05)$. Table 1 presents the laboratory parameters of the study population. ACD and ACD+IDA groups had significantly higher serum hepcidin concentrations than controls $(\mathrm{p}<0.001, \mathrm{p}<0.001)$, and NA group ( $\mathrm{p}=0.006, \mathrm{p}=0.002$ ). No difference in hepcidin levels was observed between ACD and ADC+IDA groups $\quad(1.18 \pm 0.68 \mathrm{vs} \quad 1.15 \pm .051$, $\mathrm{p}=0.85$ ) and between NA and controls $(0.60 \pm 0.48$ vs $0.45 \pm 0.19, \mathrm{p}=0.66)$.

Figure 1 displays the hepcidin levels in the study groups.

In the RA group $(\mathrm{N}=54)$ patients, the serum hepcidin concentration correlated significantly negatively with $\mathrm{Hb}(\mathrm{r}=-0.459)$ and serum iron( $\mathrm{r}=-0.357, \mathrm{p}<0.01$ (Figure2).

Even though ACD group had $\mathrm{Hb}$ levels higher than patients from ACD+IDA group $(11.1 \pm 1.5$ vs10.2 \pm 1.6$)$ the difference was not statistically significant. Red cell indices (MCV, MCH, MCHC) were not different between ACD and ACD+IDA groups. Ferritin levels were significantly lower in ACD+IDA group when compared with NA group $(52.5 \pm 3.2$ vs. $134.5 \pm 130.5, \mathrm{p}<0.01)$ and control $(52.5 \pm 3.2$ vs. $125.9 \pm 101.3, \mathrm{p}<0.01)$. A significant difference in sTfR values and serum iron levels (Table 1) between the $\mathrm{ACD}$ and ACD+IDA groups was observed as expected (Table 1).

Anemic profile, acute phase reactants and hepcidin values ac-

$58.26 \pm 14.24$ for the anemic group, $52.25 \pm 15.96$ for the non-anemic group, and $57 \pm 14.64$ for control. Disease duration for RA was not significantly different between the RA subgroups:

\section{cording to the FOBT tests}

Patients from the RA anemic group $(n=38)$ were investigated for FOBT. A total of 34 samples were collected: 25 patients had 


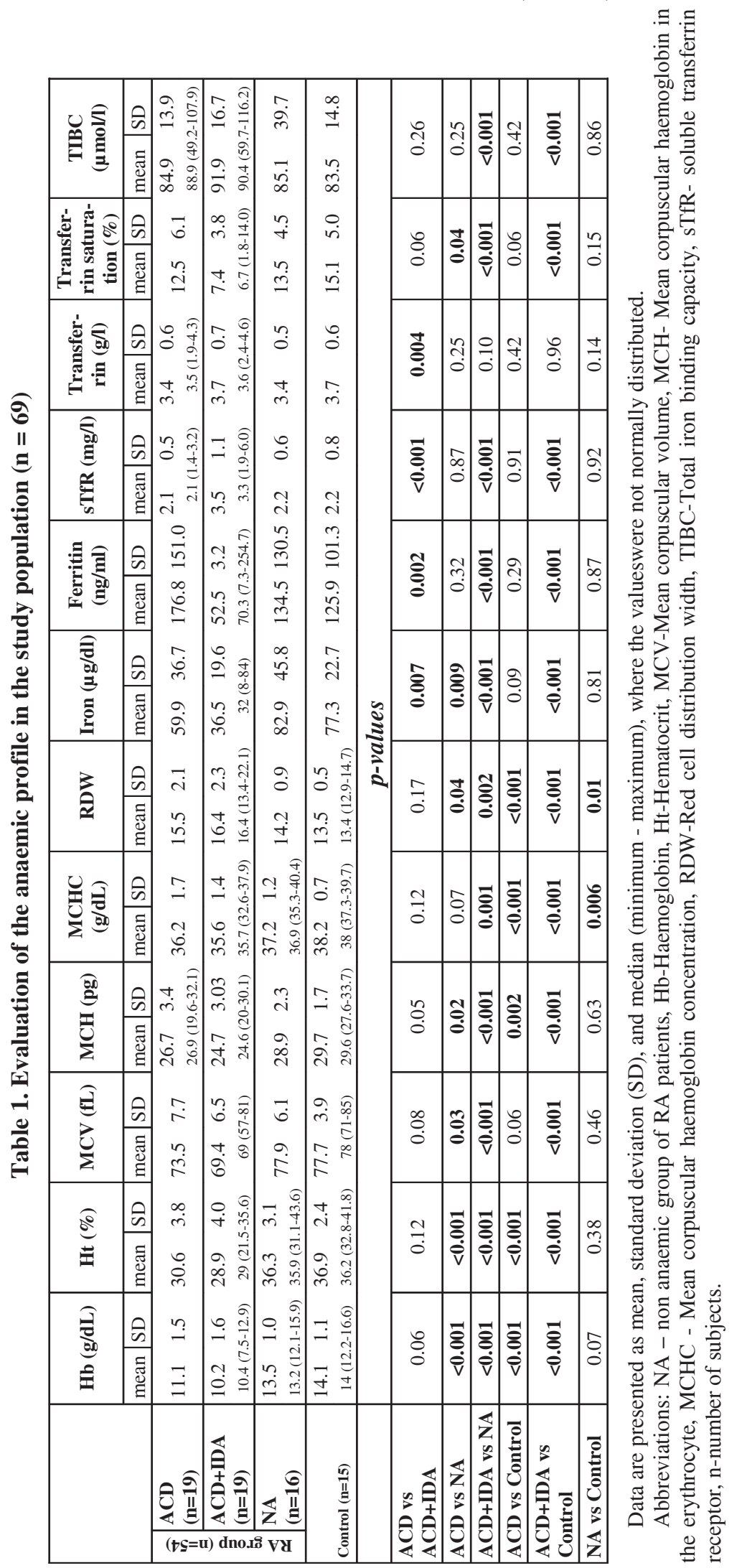


Table 2. Anaemic profile, acute phase reactants and hepcidin values in RA patients with positive and negative FOBT results

\begin{tabular}{|c|c|c|c|c|c|}
\hline \multirow{3}{*}{ Hb (g/dl) } & \multicolumn{2}{|c|}{$\begin{array}{c}\text { FOBT } \\
\text { negative }\end{array}$} & \multicolumn{2}{|c|}{$\begin{array}{c}\text { FOBT } \\
\text { positive }\end{array}$} & \multirow{3}{*}{$\begin{array}{r}\text { p-value } \\
0.122\end{array}$} \\
\hline & 11.1 & 1.4 & & 1.9 & \\
\hline & \multicolumn{2}{|c|}{$11.2(7.5-12.9)$} & \multicolumn{2}{|c|}{$10.4(6.5-11.9)$} & \\
\hline Ht $(\%)$ & 30.9 & 3.4 & 28.2 & 4.5 & 0.109 \\
\hline $\operatorname{MCV}(\mathbf{f l})$ & \multicolumn{2}{|c|}{$73(55-87)$} & \multicolumn{2}{|c|}{$75(58-81)$} & 0.906 \\
\hline \multirow{2}{*}{ MCH (pg) } & 25.8 & 3.1 & 25.1 & 3.7 & 0.667 \\
\hline & \multicolumn{2}{|c|}{$25.7(19.6-32.1)$} & \multicolumn{2}{|c|}{$24.7(20.1-30.1)$} & \\
\hline \multirow{2}{*}{ MCHC (g/dl) } & 35.9 & 1.3 & 35.2 & 2.2 & 0.531 \\
\hline & \multicolumn{2}{|c|}{$35.9(33-38.4)$} & \multicolumn{2}{|c|}{$35.8(31.1-37.8)$} & \\
\hline RDW \% & 15.8 & 2.4 & 16.4 & 2.1 & 0.369 \\
\hline \multirow{2}{*}{$\mathrm{Fe} \mu \mathrm{g} / \mathrm{dl}$} & 55.5 & 29.9 & 32.7 & 17.2 & 0.018 \\
\hline & & & \multicolumn{2}{|c|}{$32(10-66)$} & \\
\hline Ferritin ng/ml & 105.2 & 88.8 & 142.7 & 217.7 & 0.627 \\
\hline sTfR mg/l & 2.6 & 1.0 & 3.7 & 1.7 & 0.025 \\
\hline hepcidin ng/ml & 1 & 0.6 & 1.5 & 0.3 & 0.007 \\
\hline \multirow{2}{*}{ ESR mm/h } & 48.6 & 23.9 & 52.3 & 38.9 & 0.769 \\
\hline & \multicolumn{2}{|c|}{$46(8-110)$} & & & \\
\hline CRP mg/l & 37.8 & 22.8 & 57.8 & 61.4 & 0.365 \\
\hline Tf $g / l$ & \multicolumn{2}{|c|}{$3.55(2.4-4.6)$} & \multicolumn{2}{|c|}{$3.53(1.9-4.6)$} & 0.860 \\
\hline \multirow{2}{*}{ TfS \% } & 11.4 & 5.7 & 7.1 & 3.9 & 0.033 \\
\hline & & & \multicolumn{2}{|c|}{$6.46(2.8-12.9)$} & \\
\hline TIBC $\mu \mathrm{mol} / \mathrm{l}$ & $89.1(5$ & 16.2) & 88.6 & 115.7) & 0.860 \\
\hline
\end{tabular}

Data are presented as mean, standard deviation (SD), and median (minimum - maximum), where the values were not normally distributed. The $\mathrm{p}$ values correspond to differences in the parameters between patients with positive and negative FOBT results.

negative FOBT results and 9 had positive tests. The anemia profile, hepcidin levels and acute phase reactants are presented in Table 2.

Patients with positive FOBT had significantly higher hepcidin values than those that were FOBT negative $(1.51 \pm 0.34$ vs. $0.99 \pm 0.59$, $\mathrm{p}<0.01)$. A significant difference in serum iron
(55.52 \pm 29.95 vs. $32.67 \pm 17.25, \mathrm{p}=0.039)$, sTfR $(2.56 \pm 1.03$ vs. $3.48 \pm 1.15, \mathrm{p}=0.033)$ and $\mathrm{TfS}$ $(11.43 \pm 5.75$ vs. $7.07 \pm 3.92, \mathrm{p}=0.044)$ was observed. There was no difference between $\mathrm{Hb}$, $\mathrm{Ht}$ and red cell indices $(\mathrm{MCV}, \mathrm{MCH}$, $\mathrm{MCHC}$ ) between patients with positive and positive FOBT tests. 
Table 3. Acute inflammatory markers and DAS 28 score in the study group $(n=69)$.

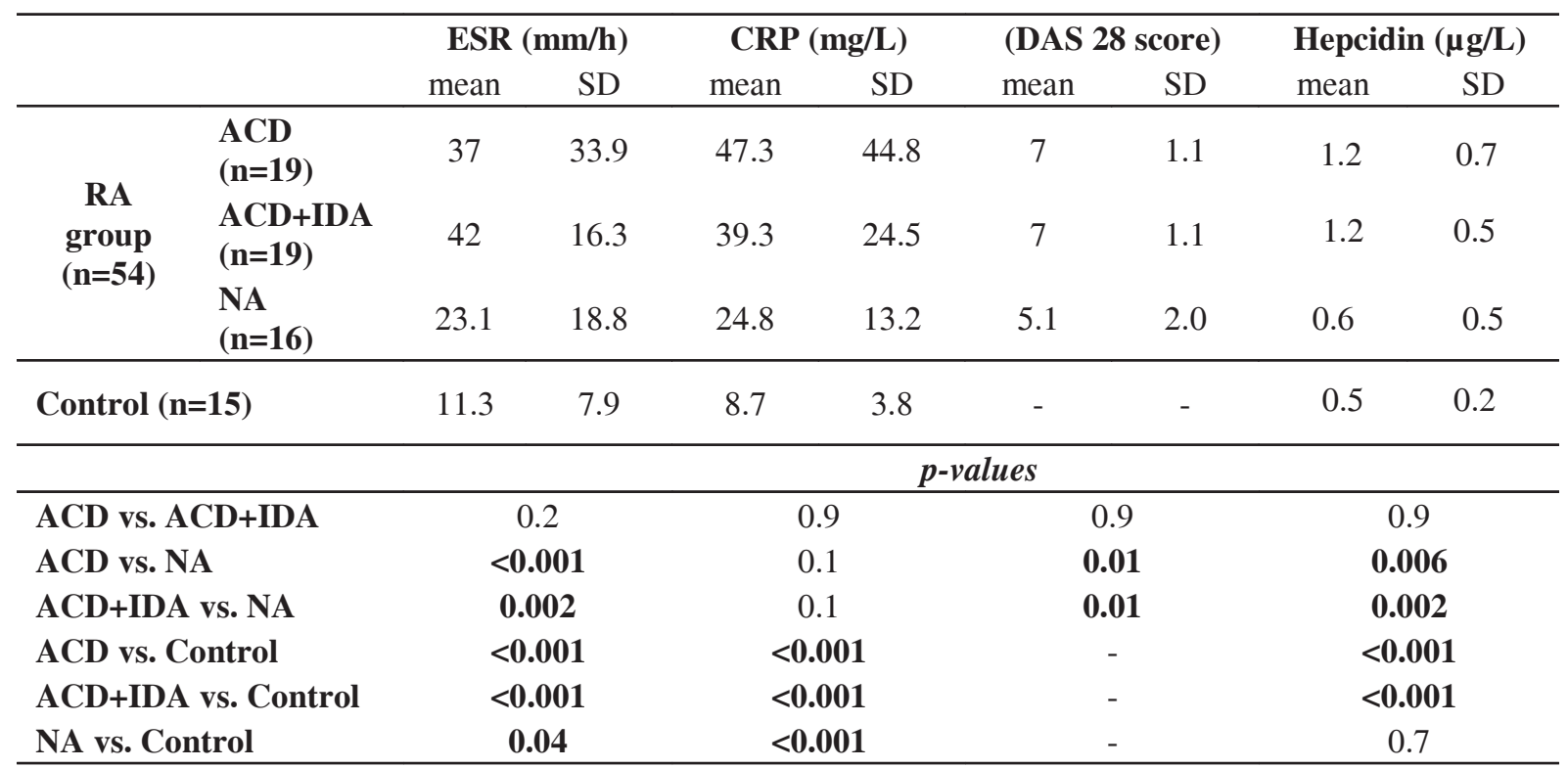

Data are presented as mean and standard deviation (SD). The $\mathrm{p}$ values correspond to differences in the parameters between RA and control groups.

Abbreviations: NA - non-anaemic group of RA patients, ESR - Erythrocyte Sedimentation Rate, CRP - C-Reactive Protein, DAS 28 score - Disease Activity Score in 28 articulations.

Inflammation markers (ESR, CRP) and DAS 28 score in patients with $R A$

Acute phase reactants (ESR, CRP) and DAS 28 score were evaluated (Table 3).

A positive correlation was observed between hepcidin and parameters used for disease activity ESR ( $\mathrm{r}=0.352, \mathrm{p}<0.01)$, CRP $(\mathrm{r}=0.369$, $\mathrm{p}<0.01)$ and DAS28 $(\mathrm{r}=0.289, \mathrm{p}<0.05)$.

\section{Discussion}

In 2000, a novel human peptide with antimicrobial activity named LEAP1 (liver expressed antimicrobial peptide) was isolated and characterized using a mass spectrometric assay (28). One year later, a group of independent scientists reported the isolation of the same peptide, which they named hepcidin (29). In the same year, results showing that hepcidin acts as a signaling molecule involved in the maintenance of iron homeostasis were published (30).
Since then, there has been a lot of interest regarding hepcidin involvement in iron metabolism disorders and reliable assays measuring the peptide in body fluids have been developed. There are only a few published studies using small patient numbers that have explored prohepcidin or hepcidin levels in individuals with inflammatory diseases and the results have been inconsistent. A study published in 2008 showed that serum pro-hepcidin levels in patients with RA and systemic lupus erythematosus (SLE) did not correlate with disease activity scores, serum iron status in the RA and SLE groups (31). Another study reported that pro-hepcidin concentration was correlated with CRP, ESR and DAS score (32), results that are similar to ours. Although we observed in our study a correlation between hepcidin and ferritin, it was not statistically significant as previous reported (33, 34). Acute inflammation induced by a single turpentine injection elicits a two-fold re- 
duction in serum iron levels in wild-type mice(35), but this effect is blunted in hepcidin deficient mice(10). These observations suggest that hepcidin plays an important role in iron homeostasis in the presence of inflammation. Our patients had a negative iron correlation with hepcidin levels, results that confirm previous assertions. Remarkably, hepcidin expression was not changed in NA group, suggesting that anemia is a stronger stimulus for hepcidin synthesis. One study reported that serum hepcidin levels in patients with different anemia profiles were statistically different from high to low: ACD, AcI $>$ ACD/IDA (AcI= acute inflammation anemia, ACD/IDA-anemia of chronic disease with concomitant iron deficiency (36). Although in our study patients from ACD group had higher serum hepcidin levels than ACD+IDA group, the difference was not significant. Patients with gastrointestinal occult bleeding had higher serum hepcidin levels than those without bleeding and also had a more active RA disease based on the DAS28 score and the correlations with acute phase reactants. According to the anemic profile, significant correlations were observed between hepcidin and $\mathrm{Hb}$ and TfS in ACD+IDA patients. Any other correlation between hepcidin and iron metabolism parameters was not statistically significant in the ACD and ACD+IDA groups. When compared the results from different studies it is important to mention that our anemic groups were classified after a cut-off value of 1.5 was applied to the anemic RA patients using the sTfRF index. Hepcidin was not able to differentiate concomitant iron deficiency in our patients, as recently demonstrated by a study conducted on a larger study population (37).

Patients with positive FOBT results tend to develop a more active disease than those with negative results (ESR: $52.33 \pm 38.92$ vs. 48.60 \pm 23.89; CRP: $57.33 \pm 61.44$ vs. $37.76 \pm$ 22.77). This could explain the increased hepcidin values in patient with fecal occult bleeding than those without $(1.51 \pm 0.35$ vs. $0.99 \pm 0.59)$.
Furthermore, this could be an argument that in the concomitant presence of anemia and inflammation, inflammation controls hepcidin expression. Hepcidin levels determined by various methods vary considerably, although the analytical variation is generally low and similar for all methods (38). Our patients had relatively low hepcidin levels compared to other studies, not only because of the test used, but also because of possible circadian variations in the hepcidin values (39); our biological samples were collected between 7:00 AM and 8:00 AM. Some of the difficulties in determining hepcidin concentrations in RA patients are related to agematched groups, duration of the disease and treatment. In addition to the difficulties linked to a non-homogeneous study population, there are difficulties related to the tests used for hepcidin determination in clinical research because hepcidin has a tendency to form aggregates and adhere to surfaces (40). There are two most important limitations of this report: firstly the absence of bone marrow examination for diagnosis of iron deficiency and secondly, the small number of subjects for each study sub-group. Given the absence of a gold standard procedure, conventional tests were used for detecting iron deficiency in our patients.

\section{Conclusion}

Serum hepcidin levels increase in patients with RA and anemia, and they correlate with $\mathrm{Hb}$ levels, serum iron and disease activity.

\section{References}

1. Wilson A, Yu HT, Goodnough LT, Nissenson AR. Prevalence and outcomes of anemia in rheumatoid arthritis: a systematic review of the literature. Am J Med. 2004; 116 (Suppl 7A):50S-7S

2. Skikne B S, Punnonen K, Caldron P.H, Bennett M.T, Rehu M, Gasior G.H.et al. Improved differential diagnosis of anemia of chronic disease and iron deficiency anemia: A prospective multicenter evaluation of soluble transferrin receptor and the sTfR/log ferritin index Am J Hematol.2011;86 (11):923-27. 
3. Weiss G, Goodnough LT. Anemia of chronic disease. N Engl J Med. 2005; 352: 1011-23

4. Bloxham E, Vagadia V, Scott K, Francis G, Saravanan $\mathrm{V}$, Heycocket $\mathrm{C}$, et al. Anemia in rheumatoid arthritis: can we afford to ignore it? Postgrad Med J. 2001; 87: 596-600.

5. Zhang X, Rovin BH, Biol Chem Beyond anemia:hepcidin, monocytes and inflammation.2013; 394(2):231-8.

6. Piperno A, Mariani R, Trombini P, Girelli D. Hepcidin modulation in human diseases: From research to clinic World J Gastroenterol.2009 ; 15(5): 538-551.

7. Swinkels DW, J F M Wetzel Hepcidin: a new tool in the management of anemia in patients with chronic kidney disease? Clinical Chem . 2002, ; 48(7):1066-76.

8. Kemna EHJM, Tjalsma H, Podust NV, Swinkels DW. Mass spectrometry-based hepcidin measurements in serum and urine: analytical aspects and clinical implications. Clin Chem. 2007; 53: 620-8.

9. Ganz $\mathrm{T}$ Hepcidin--a regulator of intestinal iron absorption and iron recycling by macrophages. Best Practice \& Research Clinical Haematology. 2005, 18(2):171-182.

10. Nicolas G, Chauvet C, Viatte L, Danan JL, Bigard X, Devaux I, et al. The gene encoding the iron regulatory peptide hepcidin is regulated by anemia, hypoxia, and inflammation. J Clin Invest. $2002 ; 110$ : 1037-44.

11. Wrighting D M, Andrews N C. Interleukin-6 induces hepcidin expression through STAT3.Blood, 2006; 108 ( 9).3204-9.

12. Nemeth E, Valore EV, Territo M, Schiller G, Lichtenstein A, Ganz T, et al. Hepcidin, a putative mediator of anemia of inflammation, is a type II acute-phase protein. Blood 2003; $101: 2461-3$.

13. Tomas Ganz. Hepcidin, a key regulator of iron metabolism and mediator of anemia of inflammation Blood . 2003102 (3) 783-788.

14. Patiu M, Lazlo G Review Iron metabolism disorder exploration .Classical and modern .Studia Universitatis Babes-Bolyai.Biologia.2007.LII.2:83-92.

15. Hebbar A Kesh, Gibson M V.Patient Care. Nov 2006:36-37 www.patientcareonline.

16. Arnett FC, Edworthy SM, Bloch DA, McShane DJ, Fries JF, Cooper NS, et al. The American Rheumatism Association 1987 revised criteria for the classification of rheumatoid arthritis. Arthritis Rheum.1988; 31 : 315-24.

17. Report of a WHO Scientific Group. Nutritional Anemias. World Health Organization, Geneva, 1968

18. Rimon E, Levy S, Sapir A. Diagnosis of iron deficiency anemia in elderly by transferrin receptor- ferritin index. Arch Intern Med. $2002 ; 162: 445-9$.

19. Choi CW, Cho W R, Park K H, Choi I K, Seo J H, Kim B S et all The cutoff value of serum ferritin for the diagnosis of iron deficiency in community-residing older persons. Annals of Hematology 2005; 84(6): 358-61.

20. Thomas L, Thomas C. Anemia in iron deficiency and disorders of iron metabolism. Deutsch Med Wochenschr.2002; 127 : 1591-4.
21. Margetic S, Topic E, Ruzic DF, Kvaternik M, et al. Soluble transferring receptor and transferrin receptor-ferritin index in iron deficiency anemia and anemia in rheumatoid arthritis. Clin Chem Lab Med.2005 ; 43: 326-31.

22. Kogan A, Filatov V, Gusev N, Bereznikova A, Kolosova O, Katrukha A, et al. Immunological study of complex formation between soluble transferrin receptor and transferring. Am J Hematol.2005 ; 79 : 281-7.

23. Shilpa J, Shashi N, Jagdish C, Sunita S, Sonal J, Priya $M$, et al. Evaluation of serum transferrin receptor and sTfR ferritin indices in diagnosing and differentiating iron deficiency anemia from anemia of chronic disease. Indian J Pediatr. $2010 ; 77$ : 179-83

24. Goyal R, Das R, Bambery P, Garewal G. Serum transferrin receptor ferritin index shows concomitant iron deficiency anemia and anemia of chronic disease is common in patients with rheumatoid arthritis in north India. Indian J Pathol Microbiol. 2008; 51(1) : 102-4.

25. Yamanishi H, Iyama S, Yamaguchi Y, Kanakura Y, Iwatani Y. Total iron binding capacity calculated from serum transferrin concentration or serum iron concentration and unsaturated iron binding capacity. Clin Chem. 2003; 49 : 175-8.

26. Thomas C, Thomas L. Biochemical markers and hematologic indices in the diagnosis of functional iron deficiency. Clin Chem. 2002 ;48: 1066-76.

27. Prevoo ML, van't Hof MA, Kuper HH, van Leeuwen MA, van de Putte LN, van Riel PL. Modified disease activity scores that include twenty-eight-joint counts. Development and validation in a prospective longitudinal study of patients with rheumatoid arthritis. Arthritis \&Rheum. 1995; 38 : 44-8.

28. Krause A, Neitz S, Magert HJ, Schulz A, Forssmann WG, Schulz-Knappe P, et al. LEAP-1, a novel highly disulfide-bonded human peptide, exhibits antimicrobial activity. FEBS Lett. 2000; 480: 147-50.

29. Park CH, Valore EV, Waring AJ, Ganz T. Hepcidin, a urinary antimicrobial peptide synthesized in the liver. J Biol Chem. 2001; 276: 7806-10.

30. Nicolas G, Bennoun M, Devaux I, Beaumont C, Grandchamp B, Kahn A. Lack of hepcidin gene expression and severe tissue iron overload in upstream stimulatory factor 2 (USF2) knockout mice. Proc Natl Acad Sci. 2001; 98: 8780-5.

31. Koca SS, Isik A, Ustundag B, Metin K, Aksoy K. Serum pro-hepcidin levels in rheumatoid arthritis and systemic lupus erythematosus. Inflammation 2008; 31: 14653.

32. Kim HR, Kim KW,Yoon SJ, Kim SH, Lee SH. Serum pro-hepcidin could reflect disease activity in patients with rheumatoid arthritis. J Korean Med Sci. 2010; 25 : 348-52

33. Dallalio G, Fleury T, Means Jr RT. Serum hepcidin in clinical specimens. Br J Haematol. 2003;122: 9961000 .

34. Roe MA, Collings R, Dainty JR, Swinkels DW, Fair- 
weather-Tait SJ. Plasma hepcidin concentrations significantly predict interindividual variation in iron absorption in healthy men. Am J Clin Nutr. 2009; 89: 1088-91.

35. Deicher R, , HÖrl W H. Hepcidin: a molecular link between inflammation and anemia. Nephrol Dial Transplant 2004 Mar; 19 (3):521-4.

36. Cheng P P, Jiao X-Y, , Wang X-h, Lin J h, Cai Ying- $m$ Hepcidin expression in anemia of chronic disease and concomitant iron-deficiency anemia Clinical and Experimental Medicine. 2010; 11(1):33-42.

37. van Santen S, van Dongen-Lases EC, de Vegt F, Laarakkers CMM, van Riel PLCM, van Ede AE, et al. Hepcidin and hemoglobin content parameters in the dia- gnosis of iron deficiency in rheumatoid arthritis patients with anemia. Arthritis \& Rheum. 2011;63: 3672-80.

38. Kroot JJC, Kemna EHJM, Bansal SS, Busbridge M, Campostrini N, Girelli D, et al. Results of the first international round robin for the quantification of urinary and plasma hepcidin assays: need for standardization. Haematologica 2009;94: 1748-52.

39. Ganz T, Olbina G, Girelli D, Nemeth E, Westerman M. Immunoassay for human serum hepcidin. Blood 2008; $112: 4292-7$.

40. Ganz T, Nemeth E. Hepcidin and disordersof iron metabolism. Annu Rev Med. 2011; 62 :347-60. 